\title{
12 \\ Building a New Thursday Circle. Carnap and Frank in Prague
}

\author{
Adam Tamas Tuboly
}

\subsection{Introduction}

When Carnap wrote a short intellectual autobiography for Marcel Boll in March 1933, he mentioned two things about Prague: (1) that he became a professor at the German University in 1931, and (2) that he worked on his Logische Syntax der Sprache until 1933. ${ }^{1}$ These things are well known. However, Carnap spent five long years in Prague, just like he did before in Vienna; so, one might ask whether (1) and (2) indeed sufficiently characterize his Prague period. Philipp Frank (1949a, 45), who had been there for almost twenty years when Carnap arrived, wrote that "[f]rom

This paper was supported by the MTA BTK Lendület Morals and Science Research Group, by the János Bolyai and the Premium Postdoctoral Research Scholarship of the Hungarian Academy of Sciences, and by the "Empiricism and atomism in twentieth-century Anglo-Saxon philosophy" NKFI project (124970). I am indebted to the Carnap Archives at Los Angeles (Rudolf Carnap papers, Collection 1029). UCLA Library Special Collections, Charles E. Young Research Library) and at Pittsburgh (Rudolf Carnap Papers, 1905-1970, ASP.1974.01, Special Collections Department, University of Pittsburgh), and to the Wiener Kreis Archiv (Rijksarchief in NoordHolland, Haarlem, The Netherlands) for the permission to quote the archive materials as "MSN" for the Moritz Schlick Nachlass and "ONN" for the Otto Neurath Nachlass. All rights reserved. The translations from the archive files are mine. I am indebted to Christian Damböck, and Brigitte Parakenings for their corrections and comments.

1"Lebenslauf [für M. Boll; 6.3.33.]" (RC 011-20-09, p. 2). This biographical note was presumably written for the French edition of Carnap's "Die alte und die neue Logik," published in 1933 as L'ancienne et la nouvelle logique (Hermann \& Cie., Paris). The volume was translated by Ernest Vouillemin, and Marcel Boll wrote an introduction. Marcel Boll (1886-1971), originally a physicist and engineer, was a French positivist philosopher and scientist who translated many papers and booklets of the Vienna Circle into French. On Boll and logical empiricism, see Schöttler (2015).

\footnotetext{
A. T. Tuboly (凶)

Institute of Philosophy, Research Center for the Humanities, ELRC, Budapest, Hungary

(C) The Author(s) 2021

C. Damböck, G. Wolters (eds.), Der junge Carnap in historischem Kontext:

1918-1935 / Young Carnap in an Historical Context: 1918-1935,

Veröffentlichungen des Instituts Wiener Kreis 30,

https://doi.org/10.1007/978-3-030-58251-7_12
} 
1931 on we [i.e., Frank and Carnap] had in this way a new center of "scientific world conception' at the University of Prague." This seems to be much more than what Carnap claimed.

Actually Carnap might have had great expectations regarding Prague: the First Conference on the Epistemology of the Exact Sciences, where the Vienna Circle publicized its manifesto, was organized by Frank there in 1929; five years later, in 1934, the Preliminary Conference of the International Congresses for the Unity of Science was hosted again in Prague. As Jan Sebestik (1994, 205) claimed, "Prague has always been one of the important European centres of learning and of science, and it has often been the forerunner of vast currents or movements, both intellectual and political." The city also had a long tradition of scientifically oriented philosophical thinking: through Bernard Bolzano, members of the Brentano School (such as Anton Marty, Tomáš G. Masaryk, Christian von Ehrenfels, Hugo Bergmann, Oskar Kraus), via Ernst Mach (who was the Rector of the University before it was divided into a Czech and a German part), to Philipp Frank and Albert Einstein, the field was well prepared for Carnap. What else could one wish for?

Things might be not that simple, however. Was Frank right, for example, when he claimed that he and Carnap built a 'new center of scientific world conception'? The aim of this paper is to provide historical evidence and further materials to approach this question. Definite answers, however, require more space and contextualization, so I will just sketch some partial but hopefully promising narratives and rudimentary answers. I claim that though Carnap and Frank indeed tried to build a new center, they were unsuccessful, and possibly there were many reasons for this. This is the general claim; regarding Carnap, I will also show his way to the German University and his philosophical, scholarly, and social life in Prague.

\subsection{The Long Struggle for a Chair (1926-1931)}

After Carnap defended his doctoral dissertation in 1921, he became an independent scholar, traveling around the world from Europe to the United States and Mexico. He did not have a permanent academic position, though he certainly would have accepted one. $^{2}$

On August 9, 1924, Schlick wrote to Carnap that he knew about his plans to habilitate in Vienna. Schlick happily encouraged the young Carnap, and the habilitation came with the possibility of becoming a Privatdozent at the University of Vienna, that is, of being qualified to become a professor at a later point. However, already in January 1926 Carnap mentioned to Schlick that Frank wrote to him about prospects of creating a brand new position in Prague, but until everything was

\footnotetext{
${ }^{2}$ Various periods of Carnap's life during the 1920 s are considered in the contributions in Damböck (2016).
} 
worked out, which could take a while, he should go with the Vienna job. ${ }^{3}$ So, even before Carnap was appointed to Vienna, he knew about Prague and could have been excited about that. But a long and interesting road was ahead of him until the end of 1931.

Carnap was not the only candidate for Prague. In April 1925, Reichenbach wrote to Schlick that he had to abandon his Stuttgart position (which he had had since 1920) and that he aimed to go to Berlin with the help of Max Planck and Albert Einstein. ${ }^{4}$ As it quickly turned out, Reichenbach faced some serious and sensitive problems in Berlin: some people (Reichenbach named Heinrich Maier) were trying to hinder him because of his leftist political activities from $1914 .^{5}$ Since Planck himself did not oppose the charges but agreed with them in principle, Reichenbach was quite afraid that he couldn't secure his existence in Berlin. ${ }^{6}$ In this unfortunate and precarious situation came a letter from Schlick in January 1926 that a certain "Lehrstuhl für Naturphilosophie," a professorship for philosophy of nature, was planned in Prague. Reichenbach already knew about this, since Frank had written to him as well: he was grateful and happy for the possibility and was willing to go to Prague. Furthermore, Schlick indicated to Reichenbach that he would be the first candidate and Carnap the second. ${ }^{7}$

Carnap - being only a Privatdozent in Vienna - and Reichenbach - getting, after all, a position as außerordentlicher Professor (associate professor) in Berlin - were invited by Frank to meet personally in Prague in 1926 and discuss their possibilities. ${ }^{8}$ Carnap got to know Frank on November 5, 1926, when he stopped by on his way from Berlin to Vienna. A month later he held two lectures in Prague, each followed by lively discussions (with some controversies, of course), and Frank ensured Carnap a few days later that the lectures had made a "good impression."

Months and actually years went by and nothing happened (except, presumably, behind the scenes). While Carnap never indicated any skepticism about Prague, Reichenbach had his ups and downs about his future prospects. Carnap noted in his diaries on April 16, 1927, that Reichenbach did not consider a job in Berlin (since he was working there already, he might have had in mind a tenure-like professorship) and he wanted to go to Prague. In June 1928, however, he wrote to Schlick that even after he had heard that things would be pressed now in Prague, he did not have any hope after being on the waiting list for two and a half years. This time, Reichenbach wanted to go to Frankfurt where the neo-Kantian Hans Cornelius and the phenomenologist Max Scheler were to retire and Ernst Cassirer would have

\footnotetext{
${ }^{3}$ Carnap to Schlick, January 15, 1926 (RC 029-32-28).

${ }^{4}$ Reichenbach to Schlick, April 22, 1925 (MSN).

${ }^{5}$ On Reichenbach's involvement in the German Youth Movement and his political affairs, see Padovani (2013), Kamlah (2013), and DAmböck (2019).

${ }^{6}$ Reichenbach to Schlick, August 10, 1925 (MSN).

${ }^{7}$ Schlick to Reichenbach, January 16, 1926, and Reichenbach to Schlick, January 24, 1926 (MSN).

${ }^{8}$ See Reichenbach to Schlick, December 6, 1926 (MSN).

${ }^{9}$ Carnap's diary entry, December 13, 1926.
} 
suggested Reichenbach for one of the chairs; so Reichenbach indicated to Schlick that in such a case Carnap should get the Prague job (though he would still be only the second on the job list). ${ }^{10}$

Two years later, in 1930, replying to Schlick, Reichenbach wrote that the Prague case was still not decided: though he wanted to go there, there were financial issues. ${ }^{11}$ In October 1931, now six years after the beginning and the first letters, Schlick wrote that he hoped that Reichenbach would not be disappointed because of Prague, and that Carnap would have a nice time there. ${ }^{12}$ In response, Reichenbach claimed that he was actually quite dejected about the Prague job, but that he had to decline the offer. He had no choice, he said, since he had to take care of the existence of his family, and this was not made possible by the economic situation in Prague. ${ }^{13}$ Though there are no details in the letter, we find some hints in Carnap's correspondence. But the point is made: Carnap was only second and thus he was able to go to Prague because Reichenbach declined their offer, he was not chosen as the first candidate! ${ }^{14}$

Carnap got a letter from Prague on June 19, 1930: as his diary entry indicates from the next day, it was about some special terms (Bedingungen) that Neurath suggested to accept: Carnap would become a professor extraordinarius with the title of a professor ordinarius. The decision was made quite hard for him since on June 21, 1930, "Schlick telephoned: title of professor in the faculty has been accepted (39 against 5)." 15 So Carnap became a professor in Vienna! In August, he met Reichenbach and they talked about Prague. The latter said that Frank and Heinrich Freiherr Rausch von Traubenberg, professor of physics in Prague, were not inclined to create a professor ordinarius position, because they want a second position in mathematics. Reichenbach seemed to suggest Carnap to accept temporarily the non-ordinarius position with the condition that it will be later transformed into an ordinarius one. ${ }^{16}$

On September 2, 1930, Carnap went to Prague and in the Ministry of Education met Dr. František Havelka and the Prodekan, the plant physiologist Ernst Pringsheim, to discuss the issues concerning the new job. Frank indicated that Traubenberg was impatient because the negotiations with Reichenbach took too long; they indicated that Carnap would have to decide quickly. ${ }^{17}$ It is not known from the documents

\footnotetext{
${ }^{10}$ Reichenbach to Schlick, July 23, 1928 (MSN).

${ }^{11}$ Schlick to Reichenbach, June 8, 1930; Reichenbach to Schlick, June 11, 1930 (MSN).

${ }^{12}$ Schlick to Reichenbach, October 23, 1931 (MSN).

${ }^{13}$ Reichenbach to Schlick, November 16, 1931 (MSN).

${ }^{14}$ It might be interesting to note that according to Feigl (1981 [1969], 61), for the Viennese position that Carnap got in 1926, Reichenbach was the other candidate, but Hans Hahn persuaded others to get Carnap because Hahn, "a great admirer not only of Mach but more especially of Russell, was convinced that Carnap would carry out in detail what was presented merely as a program in some of Russell's epistemological writings".

${ }^{15}$ Carnap's diary entries for June 19, 20, 21, 1930.

${ }^{16}$ Carnap's diary entry, August 10, 1930.

${ }^{17}$ Carnap's diary entries, September 2 and 4, 1930.
} 
when Carnap accepted the job offer with their conditions, but he got to know in August 1931 that he had been appointed already on June 30, though it did not immediately become legally valid (rechtskräftig); it still wasn't in late October, when he started to teach, or in December, when he wrote his first longer report about Prague. ${ }^{18}$ He was just an assistant (Supplent), not a professor, even in the next semester, in March $1932^{19}$; this meant that his salary was quite reduced. The ministry told Carnap in 1932 that everything was in order and only translational things were to be done; he was skeptical, though, and with good reason. He noted in his diaries that when he came back to Prague from the 1935 Paris Congress, Dr. Havelka claimed that "the promotion to Ordinarius has a good chance, but the earliest date is January [1936]."20 Since Carnap left Prague in December 1935, he never actually became a professor ordinarius there.

What conclusions and observations should we draw from these data? (1) During the 1920s, Reichenbach was much more respected and wanted in philosophical circles than Carnap: until 1926, Reichenbach published two monographs (Relativitätstheorie und Erkenntnis apriori, 1920; Axiomatik der relativistischen Raum-Zeit-Lehre, 1924), his doctoral dissertation in Zeitschrift für Philosophie und philosophische Kritik (1915) and more than twenty articles, mainly in physical journals. Carnap, on the other hand, published his doctoral dissertation and two articles in Kant-Studien, another paper in Annalen der Philosophie und philosophischen Kritik, and finally a short monograph about Physikalische Begriffsbildung (1926). While Reichenbach's wider recognition is understandable, we now have some more evidence about its effects as well.

(2) The considerations in this section about Carnap's struggle also suggest that he did not simply continue his philosophical career and projects in Prague after Vienna, but was quite lucky that he had lower requirements and existential needs than Reichenbach, and that the latter declined an offer he actually really wanted to take. It would be an interesting counterfactual history, especially for the history of philosophy of physics, to ask what would have happened if Reichenbach had joined Frank in Prague already around 1928 when he was just about to publish his Philosophie der Raum-Zeit-Lehre.

\subsection{Carnap in Prague}

With regard to Carnap's Prague time, I will briefly discuss three aspects of this period: his lectures, his philosophical works, and his cultural life.

\footnotetext{
${ }^{18}$ Carnap to Schlick, December 7, 1931 (RC 029-29-15).

${ }^{19}$ Carnap to Schlick, March 2, 1932 (MSN).

${ }^{20}$ Carnap's diary entry, October 2, 1935.
} 


\subsubsection{Carnap's Lectures}

Let's start with the list of lectures (Vorlesungen and Seminare) Carnap had, after his inaugural lecture on "The Task of the Philosophical Foundation of Natural Science," ${ }^{21}$ between the 1931 and 1935 winter semesters.

\section{WS [= Wintersemester $]^{22}$}

(1)Naturphilosophi[sche Strömungen der Gegenwart]

(2)Grundlagen der Arithmetik

\section{SS [= Sommersemester]}

(1)Einführung [in die wissenschaftliche Philosophie] (UCLA 03 - CM10) [4]

(2) Grundlagen der Geometrie (RC 089-62-02) [Ina + 3]

\section{WS}

(1)Logik I (lots of participants, in the bigger lecture-room)

(2)System der Wissenschaften: Eine Einführung in die Erkenntnistheorie (RC 089-61-01)

\section{$1933 \mathrm{SS}$}

(1)Logik II

(2)Kritische Geschichte der Philosophie der Neuzeit (RC 085-66-02)

\section{WS}

(1)Naturphilosophi[sche Strömungen der Gegenwart] [44!]

(2) Grundlagen der Arithmetik [14; Ina + 2 later]

\section{SS}

(1)Einführung in die wissenschaftliche Philosophie [6]

(2) Grundlagen der Geometrie

\section{WS}

(1)Naturphilosophische Strömungen der Gegenwart [5-6]

(2) Mengenlehre (RC 085-04-02, in shorthand)

\section{SS}

\section{(1)Logik I [6]}

(2)System der Wissenschaften: Eine Einführung in die Erkenntnistheorie [10]

\section{WS}

\footnotetext{
${ }^{21}$ Carnap to Schlick, December 7, 1931 (RC 029-29-15).

${ }^{22}$ At German-speaking universities, "Wintersemester" usually covers the period between early October and late March, while the "Sommersemester" covers early April to late September.
} 
(1) Logik II [5, then 2]

(2) Kritische Geschichte der Philosophie der Neuzeit (RC 085-66-01;085-66-02)

What can be seen from this list? First of all, the depressingly low number of students is telling. Carnap marked with an exclamation mark the 44 participants of the Naturphilosophische Strömungen der Gegenwart lecture in the 1933 winter semester. Though he did not give a number in the diaries, he emphasized the fact of the numerous participants of the Logik I lecture in the 1932 winter semester. All the other lectures and seminars were sparsely attended. The typical diary entries about these lectures registered an average of 5 students, though usually Ina, Carnap's wife, was one of them.

What is even more striking is the comparison of Prague to Vienna: in his circular letter (Rundbrief), Carnap noted that he has the same Einführung in die wissenschaftliche Philosophie course that he had already for years in Vienna. The only difference is that while 14 students attended it in Prague, he had 150 "registered participants" in Vienna. ${ }^{23}$ But as he noted in his diaries, with time, those 14 became occasionally just 4. Since these numbers did not change in any positive manner during his five-years stay in Prague, Carnap noted thelack of the students to participate in his courses with sadness, bitterness and at times anger.

We would have a clearer picture if we knew the exact number of students enrolled at the universities in Prague and Vienna, respectively. It is quite possible that the number of students at Carnap's courses in Prague in relation to the number of students at the University is not that depressing after all and we should put a different weight on the numbers above. Nonetheless, what matters here is Carnap's own perspective, and he experienced the situation as quite depressing: even if the ratio of his students to the students enrolled at the University was promising, working now with 5 students instead of talking to 150 might have come as a loss of prestige in his perspective.

Some of Carnap's lecture notes are preserved in shorthand, transcript, or typed forms. Instead of going through them individually, I just note that Carnap had lectures which were somehow connected to his research, and did not start anything entirely new. While this might not be surprising, it also suggests that we should look into Carnap's work outside the seminar rooms.

\subsubsection{The Thursday Colloquium (s)}

In 1999, Gereon Wolters wrote a quite pessimistic paper about the logical empiricists' philosophy of biology: he claimed that the logical empiricists did not have any proper, deep, or relevant philosophy of biology since the wrong people asked the wrong questions in their wrong (highly ideological) frameworks.

\footnotetext{
${ }^{23}$ Carnap's circular letter, March 2, 1932 (RC 102-67-01) (cf. Iven 2015, 134-135).
} 
In 2015, Wolters gave a talk, a refined and revised version of his 1999 paper. Though the general outlook of the new one is the same, Wolters noted the important efforts of (at least some) logical empiricists to deepen their knowledge in the philosophy of biology. By discussing the Prague "Vorkonferenz" with the Paris/ Copenhagen Congresses, Wolters (2018) argues that "from 'Prague', via 'Paris' to 'Copenhagen' we see a sort of positive gradient as to special problems in the philosophy of biology: It goes from zero in Prague via old questions in Paris to information about actual biological science, inviting philosophical analysis in Copenhagen." In order to facilitate his arguments and points, Wolters recalls some lectures of a Colloquium, organized by Frank and Carnap at Prague in 1935. In fact, this is the only reference to Carnap and Frank's Colloquium in the literature that I am aware of.

Before I discuss this Colloquium, I have to note that the cooperation between Carnap and Frank dates back to as early as $1932 .{ }^{24}$ In one of his first report letters about Prague, Carnap wrote to Schlick on March 2, 1932, that he "started a Thursday-night circle [Donnerstagabendzirkel] with Frank." We do not have much information about this group: Carnap wrote that there were especially many Russians and followers of the Brentano school, who were capable of discussing problems rationally and deliberately. In the letter, we found that their issue was Carnap's (1959 [1932]) "Metaphysics" paper, presumably the "Überwindung" one that was published already. ${ }^{25}$

The "first session" of the Circle (called by Carnap in the diaries as "our Circle") was on January 14, 1932, at Frank's place, with the following participants: Ina Carnap; the Russian Georg Katkov and Walter Engel, both of whom belonged to the third generation of the Brentano school; Sergius Hessen, a Russian philosopher and educationalist, one of the founders and editors of the international journal Logos and a neo-Kantian dialectician by education. Another participant was presumably Felix Weltsch, a close friend of Franz Kafka and a well-known organizer of Jewish life in Bohemia, having two doctorates, one in law and one in philosophy. Finally, there was Karl Reach, a student of Carnap, who attended many of his lectures and is known for a paper on "the name relation" and logical antinomies published in The Journal of Symbolic Logic (1938). Carnap noted that while Katkov and Weltsch understood his points well, Hessen did not get much of it; unfortunately, the latter led the discussion, "debating violently."26

According to the diaries, the Circle did not work out well, because it had only three more sessions. On January 21, they had an "interesting" meeting: the mathematician Karl Löwner, who became known worldwide later at Stanford as "Charles Loewner," was also there and made "clear remarks," but that is all that we know.

\footnotetext{
${ }^{24}$ There is no indication yet of Frank's having an own circle without Carnap, or before Carnap's arrival. Since most of Frank's papers from this period have been destroyed or lost we have to rely on secondary materials, but none of them suggest so far that Frank had organized anything; quite the contrary, as we will see.

${ }^{25}$ Carnap to Schlick, March 2, 1932 (MSN).

${ }^{26}$ Carnap's diary entry, January 14, 1932. On the Brentano school, see the essays in Kriegel (2017); on the life and works of Hessen, see Hans (1950).
} 
One week later (January 28) Carnap noted a "Colloquium" discussing syntax, but without any further information about the details. Finally, again one week later, on February 4, Carnap became "impatient with Hessen," even though Frank tried to mediate between them: Carnap explained that he did not think anymore that it was possible for them to understand each other. ${ }^{27}$ Since nothing is indicated in Carnap's diaries or letters about the Circle, a Colloquium, or about regular meetings and discussions, seemingly Hessen's temperament and incomprehension brought the First Prague Circle to an end.

A few years of silence lay ahead of Carnap and Frank on this front. After Carnap's lectures in London, the appearance of Logische Syntax der Sprache, and the famous pre-conference, Carnap noted in his diaries in November 1934 that Frank wanted to talk with others about the logical problems of quantum mechanics: besides discussing special questions of matrix operations and various formulations of the theory, Frank thought that "this would be a good test for the fruitfulness of scientific logic [wissenschaftliche Logik]." ${ }^{28}$ A few months later, on February 9, 1935, Carnap wrote: "Frank by us. Plans for a Colloquium." ${ }^{29}$ And that is indeed what they did. The first session came a month later. The group was called "Colloquium for the Philosophical Foundations of the Natural Sciences." As the topic of the 1935 summer semester, they chose questions of "Physics and Biology."

Frank, as the first speaker, talked on March 18 about "What do the new theories of physics mean for boundary questions of physics and biology?" Among the discussants we find, for example, Joseph Gicklhorn, who was first of all a biologist with an interest in the human sciences and history; in February 1931, before Carnap went to Prague, Gicklhorn held a lecture in the Verein Ernst Mach about cell physics. ${ }^{30}$ Other participants were Johannes Paul Fortner, a zoologist; Reinhold Fürth, who was an experimental physicist, studying with and working next to Frank for almost 15 years $^{31}$; Ludwig Berwald, a professor of mathematics working on geometry; and Karl Löwner.

According to Carnap's diaries, there were eight more meetings. One week later (March 25) Frank talked again, but this time Ernst Pringsheim was also there with Kostja Zetkin, a German physician, social economist, and lover of Rosa Luxemburg. Zetkin, after fleeing from Moscow, worked as a physician in Prague between 1935 and 1938.

At the next meeting (April 1), Gicklhorn presented a lecture. The new participants were Trude Schmidl-Waehner, an Austrian painter, and the Viennese biologist Felix Mainx, who later wrote about the "Foundations of Biology" for the International Encyclopedia of Unified Science. A certain Dr. Keller and Hans Zeisel

\footnotetext{
${ }^{27}$ Carnap's diary entry, February 4, 1932.

${ }^{28}$ Carnap's diary entry, November 30, 1934.

${ }^{29}$ Carnap's diary entry, February 9, 1935.

${ }^{30}$ Carnap's diary entry, February 18, 1931.

${ }^{31}$ Fürth (1965) gives some impressions about his Prague time with Frank.
} 
were there as well; the latter was a sociologist and legal scholar from Vienna, whose memoirs of Carnap were published posthumously (Zeisel 1993).

At another session (May 13) Pringsheim talked about whether "biology has its own laws"; as Carnap noted in the diaries, he criticized various details of the presentation with Frank and Fürth. The fifth occasion was Carnap's lecture (May 27): "The relation between biology and physics, from the viewpoint of the logic of science." As it was claimed in the diaries, Pringsheim and Adolf Pascher, director of the Institute of Botany, were sympathetic to the presentation, while "Gicklhorn thought, 'too much physics'."

The next two meetings (June 6 and 10) were merely mentioned in the diaries, but nothing was said about them. The final two occasions, held in the next semester, were devoted to Mainx (who talked about genetics, November 11) and to Fürth (“Are physical processes continuous or discontinuous?", December 2). The lecture was followed by a discussion about probability and wave functions between Carnap, Frank, Fürth, and presumably Paul Hertz, a German physicist and philosopher of science who was fleeing from Nazism first to Switzerland, then to Prague. (Hertz was actually the co-editor with Schlick of Helmholtz's (1977 [1921]) epistemological papers.)

What follows from the above considerations? (1) There were only a few scholars who attended the small number of meetings; these scholars were indeed working on biology and physics, so the group could fulfill its task of investigating the relations between physics and biology. This also support Wolters' claim that the group was inaugurated to get a closer look at (the philosophy of) biology. Frank (1936) indeed gave a talk on the relation of physics to biology at the 1935 Paris Congress; one year later at the Second Congress in Copenhagen the topic was "The Problem of Causality - with Special Consideration of Physics and Biology." 32

(2) What is also salient is the wide range of intellectuals attending the Circle: painter, physician, physicist, biologist, mathematician, sociologist, zoologist, and botanist. It would be again a piece of counterfactual history-writing to imagine what would have happened if Carnap and Frank had had more time and energy. But before we become too optimistic or sentimental, note that in 1935 Neurath asked Carnap in a letter whether something came out of the colloquium and whether anyone could deliver a talk at the forthcoming Paris Congress. Carnap said in his reply that unfortunately only Frank and he would be able to do that; he also mentioned Gicklhorn but claimed that he could not emphasize well the theoretical questions of the logic of science. ${ }^{33}$

Considering the fact that next year Carnap emigrated to the United States and two years later Frank followed him, one might plausibly claim that the discussion

\footnotetext{
${ }^{32}$ On the congress, see Stadler (2015 [2001], 178-182). Frank's and the logical empiricists' philosophy of biology is taken up in Hofer $(2002,2013)$.

${ }^{33}$ Neurath to Carnap, May 11, 1935 (RC 029-09-55), and Carnap to Neurath, May 15, 1935 (RC 029-09-54).
} 
group was not able to achieve anything similar to the Vienna Circle and Frank could not build a functioning school or center with Carnap in Prague. ${ }^{34}$

Discussion groups and circles were quite regular, however, in Prague (similarly as they were in Vienna): both cities presented a certain "culture of circles." Prague had its own Philosophy Circle (Cercle philosophique de Prague), directed by such pupils of Edmund Husserl as Ludwig Landgrebe and Jan Patoćka. After Husserl became their honorary member in May 1935, he delivered a lecture in November about "The Crisis of the European Sciences and Psychology." Carnap noted in his diaries that he did not attend Husserl's lecture, though it attracted Felix Kaufmann from Vienna. ${ }^{35}$ Besides the Philosophy Circle, there was a linguistic circle (more on it below) and the Brentano Association, hosting the Brentano Nachlass. These groups, associations, and circles, having numerous members and sympathizers, were not entirely hostile to logical empiricism, though they expressed more criticism than support.

Actually, neither Frank nor Carnap could function as the "big locomotive" of the alleged "new center in Prague," and thus they were not able to develop any unified or recognizable brand. If Carnap and Frank had any recognition in Prague, they had it through Vienna's 'Vienna Circle'. ${ }^{36}$

\subsubsection{Carnap's Philosophical Life}

Carnap (1963a, 33) says in his famous intellectual autobiography that "[m]y life in Prague, without the [Vienna] Circle, was more solitary than it had been in Vienna. I used most of my time for concentrated work, especially on the book on logical syntax." According to the diaries, Carnap did indeed spend most of his time and energy on the syntax manuscript. He worked, however, in relative isolation: he was invited to the Linguistic Circle of Prague by Roman Jakobson only in February 1935, and he delivered a talk about "Logische Syntax der Sprache" three months later, that is, only after the publication of the Syntax book. ${ }^{37}$ There is no evidence of any earlier direct contacts between Carnap and the structural linguists of Prague, though their circle was very similar to the Vienna Circle; they even had their own journal and manifesto from 1929 to propagate their modernist worldview. ${ }^{38}$ Carnap was more active, however, in the Mathematical Circle (Mathematisches Kränzchen), where he

\footnotetext{
${ }^{34}$ While seemingly the discussion group on physics and biology did not have a major impact on Carnap as a philosopher of physics and biology, Uljana Feest and Thomas Mormann argue further in the present volume that Carnap was unsuccessful also as a philosopher of psychology.

${ }^{35}$ Carnap's diary entry, November 15 and 16, 1935 .

${ }^{36}$ It should be mentioned, however, that many philosophers visited Prague during these years: W. V. O. Quine, Alfred Tarski, and Carl G. Hempel, to name just a few. Nonetheless these scholars went there especially because of Carnap and not because of an internationally well-recognized school or center, as it often happened in the case of the Vienna Circle.

${ }^{37}$ See Carnap's diary entries from February 11 and May 20, 1935.

${ }^{38}$ On Prague's Linguistic Circle, see Broekman (1974).
} 
presented three lectures (one on Hilbert, another on Gödel, and a third about general axiomatics) and attended many others. ${ }^{39}$

But Logische Syntax was not the only publication of Carnap's during his Prague period, and so the questions arise what Carnap was working on, and whether any special influence on his thought can be detected that emerged particularly during the Prague time. ${ }^{40}$

Some of the most famous papers that appeared around 1931 and 1932 were written before Carnap moved to Prague. Among these, we find "Überwindung der Metaphysik", "Die physikalische Sprache als Universalsprache," and "Psychologie in physikalischer Sprache." Though Carnap's response to Edgar Zilsel and Karl Duncker was written in Prague, it was composed in the first months (his "Protokollsätze" paper a bit later), so nothing of particular influence could be detected there.

Besides some reviews, there is nothing from 1933. Among the publications from 1934, we find "On the Character of Philosophic Problems," which was written especially for "America" and is based on Carnap's Swedish and Danish lectures from 1932 to $1933 .{ }^{41}$ Obviously, there is the Syntax book, some minor writings on pragmatism and on mathematics, but also his volume for Neurath's Einheitswissenschaft, the English translation of his "Physikalische Sprache" paper, and the lesser-known "Theoretische Fragen und praktische Entscheidungen." The latter ends with an interesting passage, claiming that metaphysics has no theoretical content, and thus cannot be refuted in the strict sense, but can be studied

\begin{abstract}
through investigations of a sociologist and a psychologist; one can determine, for example, that it is here a matter of wish fulfillment and similar things, whose systematic advancement and diffusion in social struggle serves as a diversion and a smoke screen.

In order to avoid misunderstanding, it should be remarked that we are not speaking here of a conscious goal but rather of the factual social function, which in the main does not come into the consciousness of the practitioners but is rather hidden by a justifying ideology. (Carnap 1934, 259-260)
\end{abstract}

This passage might sound as if Carnap has learnt the lessons of Frank about the sociological determination of theories and metaphysical ideas. But "ideology" as some form of "false consciousness" is much closer to Neurath than to Frank: the

\footnotetext{
${ }^{39}$ See Carnap's diary entries from January 15, 22, February 5, November 25, 1932, and January 19, 1934.

${ }^{40}$ It should be mentioned, though, that there is a file in the Carnap Archive at Los Angeles (UCLA 03 - CM10) entitled "Einführung in die wissenschaftliche Philosophie," on which Carnap worked for years (apparently between 1929 and early 1931) before his Prague time. Besides a few pages of something like an analytic table of contents for two volumes, the file consists mainly of 150 pages of shorthand notes. Some of these are dated as "November 1931," so presumably he was using this material for teaching the "Einführung" course in Prague as well. The text is a sort of introduction into scientific philosophy, summarizing the main issues of the early 1930s: overcoming metaphysics, and the foundations of the special sciences (empirical as well as formal); the first volume was headed "The Language of Science," the second "The Foundations of the Sciences." I am grateful to Christian Damböck for calling my attention to this file.

${ }^{41}$ See Carnap's diary, November 14, 16, 18, 1932 and June 24, 1933.
} 
latter's 1932 book on causation did not consider explicitly the question of ideologies, and even later Frank's concept was related rather to Karl Mannheim and Robert Merton than to Marx. Carnap's diaries testify, however, that he was aware of the Marxist notion of ideology through various lectures and reading groups, usually advocated by Neurath, and also spoke often with the Marxist Walter Hollitscher. ${ }^{42}$

In 1935, Carnap published his London lectures as "Philosophy and Logical Syntax," a paper on psychology and the philosophy of mind in French (presented at a Paris symposium on psychology and the natural sciences), another mathematical passage that was cut from Syntax, and his 1934 Prague Vorkonferenz paper, "Formalwissenschaft und Realwissenschaft."

Again, what do these publications show us? Carnap was indeed working on his Syntax book, and many of his publications were related to that project. Though he noted later that he learned a lot about the philosophy of physics from Frank, he did not present anything particularly relevant to that in his publications - nor anything about the philosophy of biology. While Logical Syntax has a few passages about these questions, they are quite general and optimistic regarding the project of unified science. Nevertheless, though these discussions with Frank and in their circle(s) did not surface in his writings, Carnap may have been reassured by them in his unified science conception, which emerged with renewed force later in the Encyclopedia.

With regard to actual philosophical works, Carnap (1963a, 39) complained that while in Vienna he could talk at least with the members of the Circle, whereas in Prague he "had even fewer opportunities for discussions with philosophers," since he belonged to the Faculty of the Natural Sciences and not to the Humanities. (As Frank (1949a, 45) noted, it was through Tomáš G. Masaryk - an influential philosopher and sociologist and the first President of the new Czechoslovakia after World War I - that the Faculty of Sciences created a professorship for natural philosophy. ${ }^{43}$ ) But there are some indications that the Faculty of Natural Sciences had some previous relations to philosophy. Frank $(1947,77-78)$ notes in his biography of Einstein that the life goal of the famous physicist Anton Lampa - who brought Einstein and Frank to Prague - was to "propagate Mach's views and to win adherents for them." Though Lampa left Prague for Vienna in 1918, his influence on the scientific community is unaccounted so far, and on the other hand, with Frank's appointment the dissemination of Mach's ideas was continued (on the influence of Mach's philosophy and the struggle over positivism in Prague, especially in the context of Frank, see Hofer 2020). Therefore, before World War I (and possibly even after it), Mach's philosophy was still prevailing among natural scientists - thus it wasn't necessary that Carnap could not talk about philosophy at his Faculty.

Nonetheless, as soon as his Vorlesungen and Seminare were over, Carnap got on the train and lectured around Europe, seeking out old and new connections. Going

\footnotetext{
${ }^{42}$ See, for example, the diary entries from May 12, 1930, April 18, 1931, and January 2, 1934. Note that the first entry dates from before his departure to Prague.

${ }^{43}$ On Masaryk's life and works, considering his relation to (logical) positivism as well, see Tulechov (2011).
} 
through Berlin (talking at Reichenbach's seminar and lecturing on the radio), he went to Copenhagen, Göteborg, and Stockholm (1932), later to Bratislava and Brno (1934). In the next year, he visited Münster to meet Heinrich Scholz and talk about the philosophy of mathematics. These various presentations picked up the questions of the nature of philosophy (which he called in Brünn the "opium of the intelligentsia"), of soul and god (a related lecture was recently published by Thomas Mormann; see Carnap 2004 [1929]), and of the natural sciences and humanities. While he talked in Prague about "the way of scientific philosophy" in the Urania (Prague's German Society, which aimed at communicating scientific results to a broader public), he also touched upon the "sociological function of metaphysics in the present" at the Society of Socialist Academics. There may have been connections to Frank - given that this was one of Frank's most favored topics during his entire career - but the talk is unfortunately not preserved.

Regarding the lines of personal influence, we must strictly distinguish the Carnap-Frank and Frank-Carnap routes. Frank's The Law of Causality and its Limits (1998 [1932]), published in 1932, contains occasional general references to Carnap, mainly with regard to his investigations into the connection of metaphysics to realism. This is not at all surprising: Carnap's (2005 [1928]) major ideas (documented in his Aufbau and Scheinprobleme) were known quite at that time, and his books were reviewed well, even by, for example, Felix Kaufmann, a peripheral member of the Circle. The lack of detailed considerations of Carnap's ideas, however, is also understandable: though Frank finished his book when Carnap arrived in Prague, he had been working on the book already around $1925 .{ }^{44}$ In the Preface, Frank acknowledged, and expressed his gratitude for, the help of physicists (Albert Einstein, Richard von Mises, Ernst Schrödinger), of biologists (Josef Gicklhorn and Fritz Knoll), ${ }^{45}$ and of sociologists (Neurath), but not to philosophers and in particular not to Carnap.

A few years later, however, Carnap became quite effective in moving Frank into new directions. After the appearance of the Syntax book, Frank often referred explicitly to Carnap's book (1949c [1936], 162, 1949d [1938], 86, 1953 [1938], 220-221) and to the logic of science (1949b [1934], 124). This does not mean that Frank started to pursue logical and syntactical inquiries; but his remarks show signs of Carnap's influence. Frank admitted the legitimacy of Carnap's approach; he even planned a lecture about logical syntax and physics for the 1938 Cambridge congress, but canceled $\mathrm{it}^{46}$; furthermore, he tried to integrate that type of investigation into a more general philosophy of science, which was recently called the "bipartite metatheory" by Thomas Uebel (2012).

Regarding the Frank-Carnap line, note first that Frank was highly respected among logical empiricists and other circles as well. (Though this may not be

\footnotetext{
${ }^{44}$ Schlick to Reichenbach, August 5, 1925 (MSN).

${ }^{45}$ Knoll was an Austrian botanist who became a professor in Prague after 1922 and in Vienna (1933). He was also a member of the NSDAP and was known later for his national-socialist views. According to the diaries, Carnap met Knoll once in Prague on December 12, 1926.

${ }^{46}$ Frank to Neurath, June 1938, Fiche 62/237 (ONN).
} 
obvious in the Circle's published writings, the correspondences of the individual members testify it.) Many of Frank's papers were translated into French as soon as they were published in German, just like his pamphlet "The Fall of Mechanistic Physics" (Frank 1987 [1937]) written for Neurath's Einheitswissenschaft. This booklet, though it is not mentioned in Frank's bibliography (in Frank 1998 [1932], 290-296), was translated into Czech after its publication (Frank 1937).

Therefore one might expect some direct and significant influences here. Even though Carnap and Frank met regularly when they were in town at the same time (actually this did not happen very often), Fürth (1965, xiv) claims that "[Frank] preferred to work on his own and never had a 'research school.' "But this does not mean that Frank's work did not have any impact on Carnap's thoughts. Carnap (1963a, 32) claimed, for example, in his intellectual autobiography that "in a way similar to Neurath, [Frank] often brought the abstract discussion among the logicians back to the considerations of concrete situations. [...] I received many fruitful ideas from my talks with him, especially on the foundation of physics."

Frank indeed had some slight effect on Carnap: he noted in his Introduction to the Philosophy of Science that according to Frank, "it is often instructive to read the prefaces of scientific textbooks" (1995 [1966], 206). Though Carnap discussed an example of how the sentence "nature never violates the laws" documents extrascientific tendencies, he did not provide details or context, only admitted the legitimacy of such inquiries.

But that book of Carnap's, which is rarely discussed except for its considerations on scientific realism and instrumentalism, may contain some surprises. Carnap presents there his ideas on many important notions of philosophy of science, and devotes some space to quantum physics as well. Since he was a trained theoretical physician, he had a good position to write about such issues, but the truth was, he wrote to Wolfgang Yourgrau in 1958, that he was not that familiar with quantum mechanics since during his education, he learned about the theory of relativity, and later he turned towards mathematics and did not follow the newest debates in and about physics. ${ }^{47}$ Thus it would be important to contrast what Carnap says in this book about physics against what Frank wrote during the 1930s, to see whether there is any line of influence there. Again, before we become too optimistic, note that Carnap claims in his diaries that just a few days before he left Prague he was able to tell Frank, after waiting for four years, an idea about the gravitational field. This does not sound like a well-balanced relation between them. ${ }^{48}$

Carnap knew well Frank's major work: after the appearance of The Law of Causality, he immediately reviewed it in Kant-Studien $(1933,275)$. His remarks are not very interesting in themselves: he does not criticize the book or pick up any particular point to develop it further. He notices the conceptual crisis of physics and appreciates Frank for his exact and clear formulations, for his inclination to write

\footnotetext{
${ }^{47}$ Carnap to Wolfgang Yourgrau, October 3, 1958 (RC 027-42-03). Actually Carnap mentioned this also in his intellectual autobiography (1963a, 14-15), where he claimed that Reichenbach used to help him with physical questions and he in turn helped Reichenbach with logical problems.

${ }^{48}$ Carnap's diary entry, December 7, 1935.
} 
for the layman, and describes the book as the "best contemporary presentation of the problem of causality." He also emphasized that Frank does not admit any philosophy beyond the sciences as a separate higher discipline.

Though the review is quite conventional, Carnap and Frank were obviously approaching philosophy and science as well as their nature and function from the same direction and they reached very similar conclusions. The abovementioned "bipartite metatheory conception", however, was in the air around that time. Carnap wrote in Logische Syntax that theory of science "in addition to the logic of science, includes also the empirical investigations of scientific activity, such as historical, sociological, and, above all, psychological inquiries" (1934/1937, 279). Frank's book contained many interesting chapters on the historical and sociological conditions of scientific, especially physical and philosophical, theories, a fact acknowledged and stressed in Carnap's review as well. ${ }^{49}$ Nevertheless, Carnap was either a philosophically minded physicist and logician or a philosopher trained in the natural sciences, but he certainly was not a sociologist of science. As he remarked later: "unfortunately a division of labor was necessary, and therefore I am compelled to leave the detailed work in this direction [the analysis of the social and cultural roots of philosophical movements] to philosophically interested sociologists and sociologically trained philosophers" (Carnap 1963b, 868).

\subsubsection{Carnap's Personal and Social Life}

From the original manuscript of his intellectual autobiography it is known that Carnap "missed painfully" that the spirit and attitude in Vienna which he encountered in the German Youth Movement. "Although [Carnap] was able to play a leading role in the philosophical work of the [Vienna Circle, he] was unable to fulfill the task of a missionary or a prophet." The United States is also mentioned: he faced similar troubles there; but nothing is said about Prague..$^{50}$ Presumably this is not accidental. Carnap was leading no one there: as we saw, he did not have a secured circle or group of regular students and he was not a public intellectual or cultural organizer.

It is also possible that Prague offered more possibilities when Frank started to work there. For example, around 1911 and 1912 the house of Berta Fanta provided the place for the so-called Fanta-Kreis (it is also known as "Café Louvre," after its first residence). Fanta was a well-known Jewish intellectual figure in the life of Prague, who was much interested in German and Czech literature, science, and arts, organizing thus a forum for the cosmopolitan elite outside the academic curriculum. Prague's most prominent scientists and artists attended the meetings, which took place before World War I: Albert Einstein, Christian von Ehrenfels, Oskar Kraus,

\footnotetext{
${ }^{49}$ On Frank's sociology of science, see Uebel (2000) and Tuboly (2017).

${ }^{50}$ Carnap, 1957, UCLA, Box 2, CM3, folder M-A5, pp. B35-B36.
} 
Franz Kafka, Max Brod, Rudolf Steiner, Hugo Bergmann, and Gerhard Kowalewski. They talked mainly about philosophy and religion, but there were also musical performances. According to many sources, Frank attended these meetings as well. ${ }^{51}$

But Berta Fanta died after World War I, and her circle was not continued. Presumably something like that would have kept Carnap busy as well. However, it should be mentioned that Carnap may have withdrawn from cultural life due to the newly emerged unsupportive atmosphere of the 1930s. In the section on "Values and Practical Decisions" of his Library of Living Philosophers volume, Carnap (1963a, 82) described how Oskar Kraus, the famous Brentano scholar from Prague, "seriously pondered the question whether it was not his duty to call on the state authorities to put [Carnap] in jail."

Carnap claimed in the early 1930s that ethical, normative, and other types of value statements do not have any theoretical or cognitive content which would be empirically and intersubjectively approachable by factual scientific investigations. They were meaningless, given a very restrictive sense of "meaning," and Carnap always made this explicit. He also admitted that these sentences have "emotive or motivating [components and meaning], and their effect in education, admonition, political appeal, etc., is based on these components" (Carnap 1963a, 81). Nevertheless Carnap was criticized by various persons who "ascribed to the problem of the logical nature of value statements an exaggerated practical significance" (ibid.). They said that if value statements didn't have theoretical, and thus demonstrable, content and validity, value statements lose their true interpretation, and this conception would lead to immorality and nihilism. As it turned out, Kraus had this problem with Carnap's conception at his seminar, and thereafter he aimed at bringing the issue before higher authorities in 1935. ${ }^{.2}$

When Kraus and Carnap met personally, however, they were able to found somecommon ground: it turned out that Carnap was not a "wicked man," and Carnap developed a "very high respect for [Kraus'] sincerity and absolute honesty in philosophical discussions, and his kindness and warmheartedness had a great personal appeal" (Carnap 1963a, 82)..$^{53}$

Regarding Carnap's personal life, one thing should be mentioned. Carnap and Ina's civil ceremony was on March 5, 1933, and the Franks were their legal witnesses. I quote Israel Scheffler, who describes Carnap's wedding and Frank's role in it as follows:

\footnotetext{
${ }^{51}$ See Wein $(2016,54)$, Smith $(1981,141$, n. 9), Pawel $(1984,145)$. See also the autobiography of Gerhard Kowalewski (1950). On Prague's cultural context in this period, see Gordin (2020).

${ }^{52}$ Kraus presumably had an even deeper problem with logical empiricists. Herbert Feigl $(1969,7)$ later told the following story: In 1920, when Einstein was again in Prague to hold a lecture, Kraus debated him "with great excitement," arguing for the synthetic a priori conception of absolute space, which was rejected by (most) logical empiricists.

${ }^{53}$ In a letter to Neurath, however, Carnap described the resolution as he met Kraus accidentally at Frank's house and Kraus admitted that their debate had cultural risk and talked it over (Carnap to Neurath, April 11-12, 1935, RC 029-09-61).
} 
[Frank served] as a witness at the wedding ceremony of Rudolf Carnap and his wife. The ceremony was conducted in Czech, which Carnap did not understand. Frank therefore acted as translator as well as legal witness. He had to convey the official's questions to Carnap in German, and then translate his answers into Czech for the official to meet the formal requirements of the rite. When the procedure began, Carnap, the meticulous logician and philosopher of language, asked Frank to clarify the meaning of the verbal formulas required. As the procedure continued, Carnap kept interjecting questions as to the logical status of the particular statements he was expected to supply at each juncture. Frank finally interrupted him, saying, in effect, "Do you want to get married or not? If so, just answer and don't ask questions!" (Scheffler 2004, 66)

Carnap wrote to Schlick that the ceremony was insignificant for them ${ }^{54}$ : they had been living together for many years, and the marriage presumably played more of a pragmatic role, for example, with regard to future traveling. Asking the Franks to be their legal witnesses, however, indicates that Carnap's social and personal life in Prague was concentrated mainly around the Franks: Philipp Frank often translated Russian movies for the Carnaps in the cinema, and the Carnaps often visited the Franks, even when Philipp was out of town.

\subsection{Conclusion: On the Road Again}

After 1933 Prague, given its general liberal atmosphere and its German-speaking university, became something of a center for German emigrants and for many others from the Balkan and the Soviet Union. Nevertheless, this paradise of diverging opinions and people was jeopardized already in 1934, when Carnap noted in his diaries that he asked Frank whether they should initiate a demonstration against nationalism with the Prague biologist and philosopher of science Emanuel Rádl (1873-1942) and other professors. While Frank agreed in principle, he thought that only a few people would join them. ${ }^{55}$ The issue behind the demonstration was presumably the question of where to place the insignia of the university. After the university was divided into a German and a Czech University in 1882, these shared certain institutes, libraries, and among other things the old insignia of 1338, which were kept in the German University. Czech politicians demanded that the insignia be kept at the Czech University, and their protests became more violent in the 1930s. On November 21, 1934, students of the German University had to hand over the regalia to the Czech part of the University. A few days later both German and Czech students became involved in the debate; the latter, outnumbering the German students, tried to attack the German University, while the Germans resisted. Finally the regalia were given to the Czech University, but nationalistic voices on both sides were intensifying from day to day, harming the relations between the nations and the universities.

\footnotetext{
${ }^{54}$ Carnap to Schlick, March 5, 1933 (RC 029-28-31).

${ }^{55}$ Carnap's diary entry, November 30, 1934.
} 
This whole event, however, was only the final straw. Carnap had been wanting to leave Prague even earlier: he aimed to obtain a Rockefeller fellowship, but in February 1934 it turned out that they did not have any philosophy position, and Carnap's project was not exactly mathematical. ${ }^{56}$ The same thing happened as with his doctoral dissertation: he worked in a grey zone. A few months later, in August, when Charles Morris arrived in Prague, Carnap explained to him why he did not have a chance any more in Middle Europe. Morris could not promise anything regarding Chicago (he emphasized the Catholic tendencies of the department and that the chair wanted Nicolai Hartmann), but he claimed to look after Carnap's case. ${ }^{57}$

Even before Morris could deliver any news, and right after Carnap found out that a lecture tour couldn't be arranged for him in New York (though Ernest Nagel tried to help him), he was invited to Harvard's 300th-anniversary conference to hold a lecture and to receive a honorary doctoral degree! "A first step towards America," he commented in the diaries. ${ }^{58} \mathrm{~A}$ few months later it turned out that Morris succeeded: Carnap was invited to the University of Chicago for the period January-March $1936 .{ }^{59}$

On December 12, 1935, Carnap went to Dresden and thence to Bremen, in order to sail to the United States. Carnap suggested as his representative and successor first Neurath (he thought, however, that Neurath would not be the best candidate for a position at the Natural Science Faculty), then Walter Dubislav, Edgar Zilsel, Carl Hempel, and the German philosopher Ernst von Aster, who in the next year emigrated to Turkey; against Reichenbach both Frank and him had "personal misgivings," and Popper was not sympathetic to Frank. ${ }^{60}$ As is known, none of these persons got the job.

After Carnap went to the States, the situation did not get any better; indeed it became worse on both sides of the ocean. In June 1936 Carnap wrote to Neurath that according to Frank, "anti-Semitism in Prague is again flourishing." ${ }^{1}$ Carnap therefore tried to help Frank to come to the United States, but this did not work out effectively in the mid-1930s. Frank had to wait in Europe for two more years, and he was able to visit America only in late 1938 and never moved back to the old continent. More interestingly, however, Carnap commented on this by saying: "The world is hoggishly arranged. Over here anti-Semitism is rampant as well, especially at the Universities, - thus, for example, I have heard that non-Aryans did not even have the slightest chance of getting the job at Princeton that I rejected.", ${ }^{62}$ Here Carnap presumably referred to Reichenbach, who complained to Louis Rougier that

\footnotetext{
${ }^{56}$ Carnap to Schlick, February 28, 1934 (RC 029-28-24).

${ }^{57}$ Carnap's diary entry, August 17,1934 . The Thomist philosophers' resistance against the logical empiricists is documented in Reisch (2005, 2017).

${ }^{58}$ Carnap's diary entry, February 28. 1935.

${ }^{59}$ Carnap's diary entry, August 5, 1935.

${ }^{60}$ Carnap's diary entry, November 25, 1935.

${ }^{61}$ Carnap to Neurath, June 11, 1936 (RC 102-52-26).

${ }^{62}$ Carnap to Neurath, June 11, 1936 (RC 102-52-26).
} 
even though Carnap had recommended him for a Princeton job, he was not able to take it because of an anti-Semitic trend there. ${ }^{63}$

It is quite well known how hard was it for emigrants in general to adapt to the new living conditions, but it is less well known what it was like for others, like Edgar Zilsel (who committed suicide), Felix Kaufmann, Alfred Tarski, Karl Menger, or Carl Hempel. That is a story still to be written - presumably an unhappy story like the one of the Prague Thursday Circle.

\section{References}

Broekman, J.M. 1974. Structuralism: Moscow - Prague - Paris. Dordrecht: D. Reidel.

Carnap, R. 1933. Besprechung, Philipp Frank, Das Kausalgesetz und seine Grenzen. Kant-Studien 38(1/2): 275.

. 1934. Theoretische Fragen und praktische Entscheidungen. Natur und Geist 2(9):

257-260.

- 1959 [1932]. The elimination of metaphysics through logical analysis of language. In Logical positivism, ed. A.J. Ayer, 60-81. Glencoe: Free Press.

- 1963a. Intellectual autobiography. In The philosophy of Rudolf Carnap, ed. P.A. Schilpp, 3-84. LaSalle: Open Court.

. 1963b. Replies and systematic expositions. In The philosophy of Rudolf Carnap, ed.

P.A. Schilpp, 859-1013. LaSalle: Open Court.

1995 [1966]. An introduction to the philosophy of science, ed. M. Gardner. New York: Dover. 2004 [1929]. Von Gott und Seele: Scheinfragen in Metaphysik und Theologie. In Rudolf

Carnap - Scheinprobleme in der Philosophie und andere metaphysikkritische Schriften, ed.

T. Mormann, 49-62. Hamburg: Felix Meiner.

- 2005 [1928]. The logical structure of the world and pseudoproblems in philosophy. Chicago/LaSalle: Open Court.

Damböck, C., ed. 2016. Influences on the Aufbau. Cham: Springer.

2019. Carnap, Reichenbach, Freyer: Non-cognitivist ethics and politics in the spirit of the

German youth movement. In Logical empiricism, life reform, and the German youth movement/

Logischer Empirismus, Lebensreform und die deutsche Jugendbewegung, ed. C. Damböck,

G. Sandner, and M. Werner. Dordrecht: Springer.

Feigl, H. 1969. The origin and spirit of logical empiricism. In The legacy of logical positivism, ed.

P. Achinstein and S.F. Barker, 3-24. Baltimore: Johns Hopkins Press.

- 1981 [1969]. The Wiener Kreis in America. In Herbert Feigl: Inquiries and provocations: Selected writings 1929-1974, ed. R.S. Cohen, 57-94. Dordrecht: D. Reidel.

Frank, P. 1936. L'abîme entre les sciences physiques et biologiques vu à la lumière des theories physiques modernes. In Actes du Congrès International de Philosophie Scientifique, fasc. 2: Unité de la science, 1-3. Paris: Hermann.

—. 1937. Rozvrat Mechanistické Fysiky. V Praze. Trans. of Frank 1987 [1937].

1947. Einstein: His life and time. New York: Alfred A. Knopf.

- 1949a. Introduction - Historical background. In Modern science and its philosophy, 1-52.

Cambridge, MA: Harvard University Press.

- 1949b [1934]. Is there a trend toward idealism in physics? In Modern science and its

philosophy, 122-137. Cambridge, MA: Harvard University Press.

${ }^{63}$ I am indebted to Flavia Padovani for this information (see Padovani 2006, 237). 
1949c [1936]. Philosophical misinterpretations of the quantum theory. In Modern science and its philosophy, 158-171. Cambridge, MA: Harvard University Press.

. 1949d [1938]. Ernst Mach and the unity of science. In Modern science and its philosophy, 79-89. Cambridge, MA: Harvard University Press.

. 1953 [1938]. Philosophical interpretations and misinterpretations of the theory of relativity. In Readings in the philosophy of science, ed. H. Feigl and M. Brodbeck, 212-231. New York: Appleton-Century-Crofts.

- 1987 [1937]. The fall of mechanistic physics. In Unified science: The Vienna Circle monograph series originally, ed. B. McGuinness and Otto Neurath, now in an English edition, 110-129. Dordrecht: D. Reidel.

— 1998 [1932]. The law of causality and its limits. Trans. M. Neurath and R.S. Cohen. Dordrecht: Springer.

Fürth, R. 1965. Reminiscences of Philipp Frank at Prague. In Proceedings of the Boston colloquium for the philosophy of science, 1962-1964, ed. R.S. Cohen and M.W. Wartofsky, xiii-xvi. New York: Humanities Press.

Gordin, M. D. 2020. Einstein in Bohemia. Princeton: Princeton University Press.

Hans, N. 1950. Sergius Hessen. The Slavonic and East European Review 29(72): 296-298.

von Helmholtz, H. 1977 [1921]. Epistemological writings, ed. P. Hertz and M. Schlick, Trans. M.F. Lowe. Dordrecht: D. Reidel.

Hofer, V. 2002. Philosophy of biology around the Vienna Circle: Ludwig von Bertalanffy, Joseph Henry Woodger and Philipp Frank. In History of philosophy of science: New trends and perspectives, ed. M. Heidelberger and F. Stadler, 325-333. Dordrecht: Springer.

Hofer, V. 2020. Philipp Frank's Civic and Intellectual Life in Prague: Investments in Loyalty. In The Vienna Circle in Czechoslovakia, ed. R. Schuster, 51-72. Cham: Springer.

- 2013. Philosophy of biology in early logical empiricism. In New challenges to philosophy of science, ed. H. Andersen, D. Dieks, W. Gonzalez, T. Uebel, and G. Wheeler, 351-363. Dordrecht: Springer.

Iven, M. 2015. Er „,ist eine Künstlernatur von hinreissender Genialität“: Die Korrespondenz zwischen Ludwig Wittgenstein und Moritz Schlick sowie ausgewählte Briefe von und an Friedrich Waismann, Rudolf Carnap, Frank P. Ramsey, Ludwig Hänsel und Margaret Stonborough. Wittgenstein-Studien 6(1): 83-174.

Kamlah, A. 2013. Everybody has the right to do what he wants: Hans Reichenbach's volitionism and its historical roots. In The Berlin Group and the philosophy of logical empiricism, ed. N. Milkov and V. Peckhaus, 151-175. Dordrecht: Springer.

Kowalewski, G. 1950. Bestand und Wandel: Meine Lebenserinnerungen, zugleich ein Beitrag zur neueren Geschichte der Mathematik. Munich: Oldenbourg.

Kriegel, U., ed. 2017. The Routledge handbook of Franz Brentano and the Brentano School. New York: Routledge.

Padovani, F. 2006. La correspondance Reichenbach-Rougier des années trente: Une "collaboration amicale", entre empirisme logique et exil. Philosophia Scientice 10(2): 223-250.

- 2013. Genidentity and topology of time: Kurt Lewin and Hans Reichenbach. In The Berlin Group and the philosophy of logical empiricism, ed. N. Milkov and V. Peckhaus, 97-122. Dordrecht: Springer.

Pawel, E. 1984. The nightmare of reason: A life of Franz Kafka. New York: Farrar-Straus-Giroux. Reach, K. 1938. The name relation and the logical antinomies. Journal of Symbolic Logic 3 (3): 97-111.

Reisch, G. 2005. How the Cold War transformed philosophy of science: To the icy slopes of logic. Cambridge: Cambridge University Press.

- 2017. Pragmatic engagements: Philipp Frank and James Bryant Conant on science, education, and democracy. Studies in East European Thought 69(3): 227-244.

Scheffler, I. 2004. Gallery of scholars: A philosopher's recollections. Dordrecht: Kluwer Academic Publishers. 
Schöttler, P. 2015. From Comte to Carnap: Marcel Boll and the introduction of the Vienna Circle. Revue de Synthèse 136(1/2): 207-236.

Sebestik, J. 1994. Prague mosaic: Encounters with Prague philosophers. Axiomathes 5(2-3): 205-223.

Smith, B. 1981. Kafka and Brentano: A study in descriptive psychology. In Structure and Gestalt: Philosophy and literature in Austria-Hungary and her successor states, ed. B. Smith, 113-159. Amsterdam: John Benjamins.

Stadler, F. 2015 [2001]. The Vienna Circle: Studies in the origins, development, and influence of logical empiricism. 2nd ed. Dordrecht: Springer.

Tuboly, A.T. 2017. Philipp Frank's decline and the crisis of logical empiricism. Studies in East European Thought 69(3): 257-276.

von Tulechov, V. 2011. Tomas Garrigue Masaryk: Sein kritischer Realismus in Auswirkung auf sein Demokratie- und Europaverständnis. Göttingen: V\&R Unipress.

Uebel, T. 2000. Logical empiricism and the sociology of knowledge: The case of Neurath and Frank. Philosophy of Science 67:138-150.

. 2012. The bipartite conception of metatheory and the dialectical conception of explication. In Carnap's ideal of explication and naturalism, ed. P. Wagner, 117-130. Basingstoke: Palgrave Macmillan.

Wein, M. 2016. History of the Jews in the Bohemian lands. Leiden: Brill.

Wolters, G. 1999. Wrongful life: Logico-empiricist philosophy of biology. In Experience, reality, and scientific explanation: Essays in honor of Merrilee and Wesley Salmon, ed. M.C. Galavotti and A. Pagnini, 187-208. Dordrecht: Springer.

—. 2018. "Wrongful life" reloaded: Logico-empiricism's philosophy of biology (Prague/ Paris/Copenhagen): With historico-political intermezzos. In 1935-2015: 80 ans de philosophie scientifique, ed. M. Bourdeau, G. Heinzmann, and P. Wagner, Special issue of Philosophia Scientiæ, vol. 22(3), 233-255.

Zeisel, H. 1993. Erinnerungen an Rudolf Carnap. In Wien-Berlin-Prag: Der Aufstieg der wissenschaftlichen Philosophie, ed. R. Haller and F. Stadler, 218-223. Wien: Hölder-Pichler-Tempsky.

Open Access This chapter is licensed under the terms of the Creative Commons Attribution 4.0 International License (http://creativecommons.org/licenses/by/4.0/), which permits use, sharing, adaptation, distribution and reproduction in any medium or format, as long as you give appropriate credit to the original author(s) and the source, provide a link to the Creative Commons license and indicate if changes were made.

The images or other third party material in this chapter are included in the chapter's Creative Commons license, unless indicated otherwise in a credit line to the material. If material is not included in the chapter's Creative Commons license and your intended use is not permitted by statutory regulation or exceeds the permitted use, you will need to obtain permission directly from the copyright holder. 